\title{
FEATURES OF STRUCTURE REORDERING AND MICROELEMENT COMPOSITION OF HUMAN ENAMEL IN THEIR PATHOLOGICAL ERASURE IN THE AGE ASPECT
}

\section{V.I. Struk}

Abstract. The paper presents the results of electron-microscopic examination and X-ray spectral analysis of the structural features and microelement composition of the enamel of human teeth in normal and their pathological wearing with age. The differences in the structure of the enamel both in the age aspect, and in the case of pathological wearing of teeth as reducing the thickness of the surficial layer, formation of the non prismoidal structure both in the depth of the enamel and in the dentin-enamel joint area. The features of the content of trace elements are established as well as a decrease in the overall level of mineralization of teeth with abnormal wearing.

Key words: electron-microscopic examination, X-ray spectral analysis, tooth enamel.

Bukovinian State Medical University (Chernivtsi)

\section{ІМУНОЦИТОФЛУОРЕСЦЕНТНИЙ АНАЛІЗ: ОСНОВНІ ЕТАПИ ФЕНОТИПУВАННЯ ТА ДИФЕРЕНЦЙНИЙ ПОТЕНЦІАЛ АВТОЛОГІЧНИХ СТОВБУРОВИХ МЕЗЕНХІМАЛЬНИХ КЛІТИН IN VITRO}

ДУ «Інститут мікробіології та імунології ім. І.І. Мечникова НАМН України», м. Харків ДУ «Інститут нейрохірургії ім. А.П. Ромоданова НАМН України», м. Київ

Резюме. У статті міститься розгорнута інформація щодо можливостей застосування імунофлуоресцентного аналізу для вивчення основних етапів фенотипування та диференціювання автологічних стовбурових мезенхімальных клітин (АСМК) in vitro. Авторами роботи представлені свідчення, що стосуються походження клітин (самці щурів лінії Вістар 3-місячного віку), способів їх отримання в лабораторних умовах (виділення із діафізів, епіфізів стегнової та великогомілкової кісток тварин із подальшим промиванням культуральним середовищем, висівом на чашки Петрі, експлантацією, відмиванням від формених елементів крові, культивуванням у моношарі, пересівом). Вказуються умови проведення фенотипування (із застосуванням проточної цитофлуориметрії, отримання ДНК полімеризацією зі специфічними праймерами та завершення полімеразно-ланцюговою реакцією). Продукти реакції аналізували методом електрофорезу в агарозному гелі. Диференціюванню в нейрональному напрямку піддавали АСМК після другого пересіву культури. Для індукції диференціювання застосовували ростовий

Вступ. Сучасна практика запровадження автологічних стовбурових мезенхімальних клітин (АСМК) вимагає кропіткого експертного аналізу вихідного матеріалу, ретельної деталізації кожного з етапів застосування стовбурових клітин, відстеження подальшої долі останніх in vitro або in vivo $[2,3,5]$. На сьогоднішній день у світі існують загально прийнятні стандарти оцінки використання стовбурових (мезенхімальних клітин, зокрема), відпрацьовані та застосовуються най- фактор нейротрофін-3. АСМК нарощували до щільного моношару. Фенотипування отриманих похідних проводили шляхом забарвлення клітин антитілами до білкових маркерів нейронів специфічного ядерного білка нейронів (NeuN) (Chemicon), нейрофібрилярного білка відростків (Тau) (Chemicon), мієлін-олігодендроцит специфічного білка (MOSP) (Chemicon), гліального фібрилярного кислого білка (GFAP) (Chemicon). У результаті дослідження встановлено, що кількість CD90+- клітин (які власне і були популяцією АСМК) становила 95-97 \%. Фенотип клітин, що визначали із залученням поверхневих маркерів, не змінювався протягом перших чотирьох пасажів. Культивування популяції АСМК протягом цих пасажів довело, що вони не втрачали здатності до диференціювання у трьох ортодоксальних напрямках. Отже, популяції АСМК залишалися гомогенними.

Ключові слова: автологічні стовбурові мезенхімальні клітини (АСМК), імунофлуоресцентний метод, фенотипування, культивування, диференціювання, маркери нейроцитів.

більш поширені та затребувані практикою протоколи (American Heart Association [American Heart Association / Heart Disease and Stroke Statistics, 2007; A Systematic Review and Meta-Analysis of Clinical Trials, 2012) [4, 14]. Однак в експертів виникає безліч питань під час остаточної морфологічної детекції, отриманих внаслідок диференціювання клітин. Жваві дискусії викликають міркування щодо класифікації і типології останніх, успішних перспектив запровадження клітинної 
трансплантації в клініці $[1,10,15]$. Непорозуміння також доволі часто бувають пов'язані саме 3 остаточною реалізацією диференційного потенціалу клітин, особливо, коли мова йде про їхню адгезію на структурах неушкодженої тканини (скажемо, кора інтактного головного мозку). Виникають питання, на кшталт того, як саме класифікувати епітеліоподібні (гліомезодермальні) клітини, що утворилися на поверхні нормальної кори під час інтракраніального уведення АСМК (пам'ятаємо про неминучі дефекти оболонок головного мозку треком хірургічної голки). Цікавим залишається питання щодо ступеня зрілості отриманих клітин. Відомо, що суттєву послугу у вирішенні зазначених завдань здатен надати імунофлуоресцентний метод дослідження. Отже, 3 огляду на останнє, його застосування для аналізу основних етапів фенотипування та диференціювання АСМК, видається актуальним та своєчасним.

\section{Матеріал і методи.}

I. Виділення, культивування АСМК із строми кісткового мозку самців- цурів лінії Bicmap

Суспензію кісткового мозку виділяли із стегнової та великої гомілкової кісток самців-щурів лінії Вістар після декапітації. У стерильних умовах видаляли епіфізи кісток, діафізи промивали середовищем для культивування, що складалося iз розчину Хенкса, 20 \% сироватки крові ембріонів корів (Gibco, США) та 100 мкг/мл пеніциліну/ стрептоміцину (Gibco, CША). Отримані змиви висівали на пластикові чашки Петрі (Sarstedt, Німеччина). Через 48 годин після експлантації кісткового мозку проводили дворазову процедуру відмивки АМСК від формених елементів крові за допомогою розчину фосфатно-сольового буфеpa (ФСБ: 20 мМ фосфатний буфер, $\mathrm{pH}=7,4 ; 0,1 \mathrm{M}$ $\mathrm{NaCl}$ ). Клітини культивували в моношарі при температурі $37^{\circ} \mathrm{C}^{\mathrm{o}}$ та $5 \% \mathrm{CO}_{2}$ протягом шестисеми діб після експлантації ( $\mathrm{CO}_{2}$-інкубатор, model BNR-110, Tabai ESPEC, Osaka, Японія). У подальшому культуру пересівали кожні сім діб, дотримуючись показників вихідної щільності у $1,27 \times 10^{3}$ клітин $/ \mathrm{cm}^{2}$. Для пересіву культури АМСК щурів використовували розчин трипсину (Нyclone, Нова Зеландія). Заміну поживного середовища виконували кожні три доби $[1,3,13]$.

\section{II. Фенотипування АСМК самців-щурів лінії Вістар \\ Фенотипування АСМК самців-щурів лінії} Вістар виконували із застосуванням методу проточної цитофлуориметрії на проточному цитофлуориметрі EPICS XL (Beckton Coulter, CША). Недиференційовані АСМК забарвлювали антитілами проти негативного маркеру CD45 (Beckton Dickinson, США) та антитілами проти позитивних маркерів CD90 та CD106 (Beckton Dickinson, США). Отриману ДНК полімеризували зі специфічними праймерами та проводили полімеразну ланцюгову реакцію. Продукти реакції аналізували методом електрофорезу в агаризованому гелі. Маркером недиференційованих АСМК був вибраний ген фібронектину. Для аналізу експресії маркерних генів методом ПЛР застосовували специфічні праймери. Їх підбирали за допомогою програми GeneRunner за послідовностями мРНК (сайт Національного інституту здоров'я США) [4].

III. Диференціювання АСМК самців-щурів лінії Вістар in vitro в нейрональному напрямку

Диференціюванню в нейрональному напрямку піддавались АСМК після другого пересіву культури $[8,12,13,16]$. Для індукції диференціювання використовували ростовий фактор нейротрофін-3. АСМК нарощували до щільного моношару. Після цього у стандартне середовище культивування додавали нейротрофін-3 так, щоб його фінальна концентрація склала $2,5 \times 10^{-6}$ г/мл. Обробка індуктором диференціювання тривала два тижні. За цим половину середовища культивування змінювали кожних три тижні. Фенотипування отриманих похідних проводилося шляхом забарвлення клітин антитілами до білкових маркерів специфічного ядерного білка нейронів (NeuN) (Chemicon), нейрофібрилярного білка відростків (Тau) (Chemicon) мієлінолігодендроцитного специфічного білка (MOSP) (Chemicon), гліального фібрилярного кислого білка (GFAP) (Chemicon). Для імуногістохімічного підтвердження клітини на чашках промивали два рази розчином ФСБ, обробляли $0,1 \%$ розчином сапоніну протягом однієї години, за цим додавали розчин моноклональних антитіл (розведення 1:100). У подальшому клітини два рази промивали ФСБ та на 30 хвилин переносили у розчин біотинільованих вторинних антитіл. Після чергового промивання ФСБ клітини обробляли розчином стрептавідин-переоксидази протягом 15 хвилин, вдруге промивали із залученням ФСБ, наносили на клітини розчин 3, 3діамінобензидину (DAB) (Novocastra). Перебіг реакції контролювали візуально із застосуванням світлооптичних систем мікроскопа Lieca (Німеччина). Забарвлені препарати заливали в пропілгалат. Морфологічні зміни оцінювали візуально із застосуванням оптичних систем мікроскопа Lieca (Німеччина).

Результати дослідження та їх обговорення. Серією проведених досліджень встановлено, що процес фенотипування АСМК складається із декількох основних послідовних етапів. За експериментально створених умов детекцією (імуноцитохімія) доведено факт диференціювання АСМК у нейрональному напрямку in vitro.

\section{I. Характеристика основних етапів фено- типування АСМК}

Перший етап дослідження складався із процедури вивчення морфологічної специфіки фенотипування АСМК самців-щурів лінії Вістар. Із зазначеною метою з'ясовували послідовності та динаміки його етапів, проводили детальний аналіз культури зазначених клітин. Незважаючи на те, що для вирішення поставленої задачі достатньо застосування первинної культури [3], для об’єктивізації 


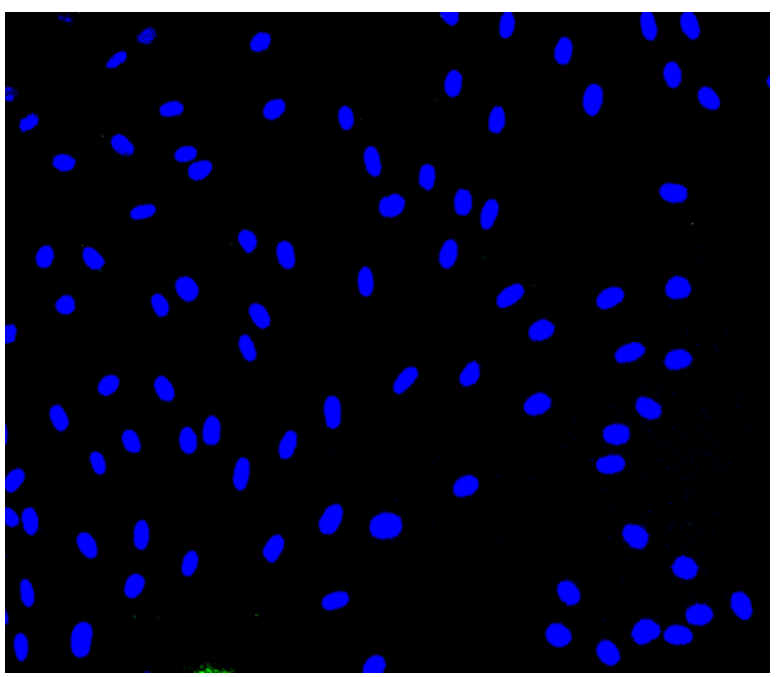

Рис. 1. Недиференційована культура АСМК. Забарвлення: нейронспецифічний (ядерний) білок нейроцитів (Neu). Флуоресцентна мікроскопія. Збільшення: х 600

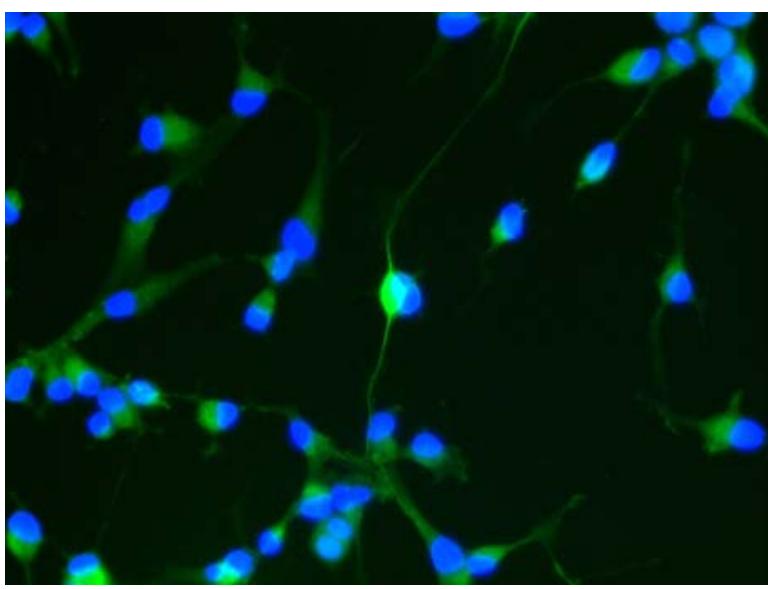

Рис. 3 Культура АСМК після нейродиференціювання. Забарвлення: нейронспецифічний (ядерний) білок нейроцитів (Neu). Флуоресцентна мікроскопія. Збільшення: x 600

результатів дослідження вдавалися до послідовних трьох пасажів. Аналіз культури АСМК третього пасажу здійснювали методом проточної цитофлуориметрії. Зазначений підхід з'ясував той факт, що кількість CD 45+6-клітин, які за структурною суттю були клітинами гемопоетичного ряду, виразно варіювали від однієї експериментальної тварини до іншої. Межа статистичної достовірності останньої становила 3-5 \% від загального числа клітин (що не суперечило даним літератури, наведеним фахівцями даної галузі $[12,13])$. Кількість CD90+- клітин, які власне і були популяцією АСМК, становила відповідно 95-97\%. Кількість CD106+-клітин досягала $15 \%$. Фенотип клітин, що визначали стандартно із залученням поверхневих маркерів, не змінювався протягом перших чотирьох- п`яти пасажів [9].

Морфологічні зміни, що візуально спостерігались у культурі, та експресія низки генівмаркерів диференційованих клітин безперечно свідчили на користь розвитку позитивної реакції (диференціювання АСМК) [2, 6]. У недиференційованих (рис. 1; рис. 2) АСМК м-РНК фібронектину експресувалася на достатньо високому рівні і

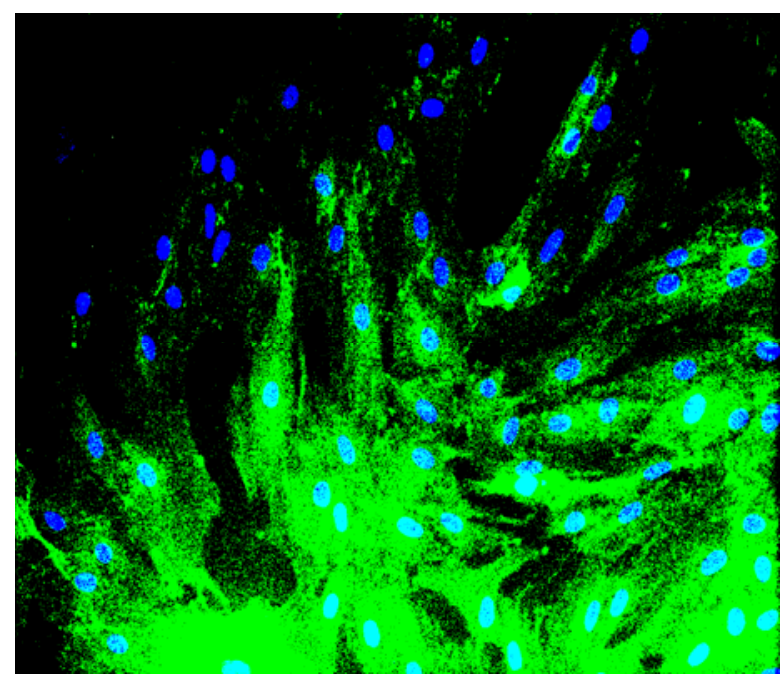

Рис. 2. Недиференційована культура АСМК. Забарвлення: специфічний гліальний кислий протеїн фібрил (GFAP). Флуоресцентна мікроскопія. Збільшення: х 600

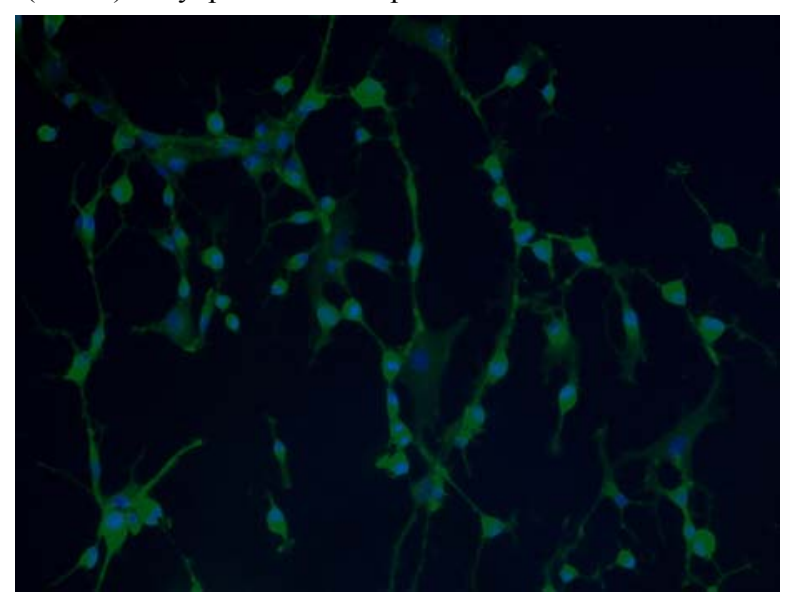

Рис. 4. Культура АСМК після нейродиференціювання. Забарвлення: специфічний гліальний кислий протеїн фібрил (GFAP). Флуоресцентна мікроскопія. Збільшення: $\mathrm{x} 600$

цей рівень знижувався за умов індукції диференціювання в будь-якому із напрямків. У разі додавання в середовище культивування індуктора остеоцитарного диференціювання морфологічні властивості популяції клітин суттєво змінювались [7].

На поверхні клітинного моношару з'являлися поля мінералізації. Індукція остеогенного диференціювання викликала значне посилення експресії остеокальцину. Аналогічною ситуація видавалась у разі апробаційного використання інших індукторів диференціювання клітин у культурі. Застосування індуктора адипоцитарного диференціювання призводило до появи ліпідних краплин (останні отримували типове для них забарвлення ліпофільним барвником Oil Red). Культивування популяції АСМК протягом чотирьох пасажів довело, що вони не втрачали здатності до диференціювання у трьох ортодоксальних напрямках. Отже, популяції АСМК залишалися гомогенними.

\section{II. Детекція АСМК та їх диференціювання} в нейрональному напрямку in vitro

Подальший аналіз отриманих в експерименті in vitro АСМК виявив спроможність останніх до 
диференціювання в нейронального напрямку (рис. 3; рис. 4). Для оцінки диференціювання застосованих стовбурових клітин використовували стандартні методики, що враховували особливості та детекційні можливості специфічних антитіл стосовно маркерних білків декількох типів клітин нервової тканини. Виконання гістологічних та ультрамікроскопічних досліджень стало передумовою до конкретизації показових 3 точки зору діагностичної ефективності антитіл на маркерні білки нейронів та гліальних клітин. Одними із них стали нейроспецифічний бета-ІІІ-тубулін, Таu- білок відростків нейронів, асоційованих 3 мікротубулами; нейронспецифічний (ядерний) білок нейроцитів, NeuN, що використовували для детекції власне нервових клітин. GFAP- специфічний гліальний кислий протеїн фібрил, головний білок цитоскелета клітинних відростків астроглії та MOSP-специфічний білок мембран олігодендроцитів сприяли підвищенню ефективності діагностики відновних процесів у віддалений період після застосування АСМК. Зазначені протеїни відігравали роль маркерних та надавали можливість досягти якісної детекції гліальних клітин. Додаванням у середовище культивування індикатора нейронального диференціювання NT3 (зумовлене методологічним змістом експерименту) домоглися цілковитого з'ясування питання стосовно морфологічної сутності проліфераційних змін у популяції нейрональних клітин та їхньої експозиції (7-14-та доба дослідження). Інтенсивне забарвлення антитілами АСМК демонструвало наявність у них маркерних білків MOSP, NeuN, NT3. Таким чином визначили білки нейронів та олігодендроцитів. Застосування даної методики для детекції білків астрогліальних клітин виявилося неефективним. У жодному з випадків реакції з антитілами в таких випадках не відбулось.

3 метою детекції АСМК застосовували забарвлення. Після додавання у культуральне середовище барвника РКН 26 через чотири години у люмінісцентному мікроскопі спостерігали характерне яскраве забарвлення-свічення АСМК. Флуоресценція була властивою внутрішнім ліпідним мембранам клітин. Подальші три послідовно виконані пересіви культури клітин підтверджували появу яскравої флуоресцентної мітки.

\section{Висновки}

1. Фенотипуванням автологічних стовбурових мезенхімальних клітин, що складалось із декількох основних послідовних етапів, які долучали процедуру з'ясування морфологічної специфіки клітин із детальним аналізом їх культури (не менше трьох-чотирьох пасажів), встановлено: кількість CD90+- клітин (які власне і були популяцією автологічних стовбурових мезенхімальних клітин ) становила відповідно 95-97 \%.

2. Фенотип клітин, що визначали стандартно iз залученням поверхневих маркерів, не змінювався протягом перших чотирьох пасажів. Культивування популяції автологічних стовбурових мезенхімальних клітин протягом цих пасажів довело, що вони не втрачали здатності до диференці- ювання у трьох ортодоксальних напрямках. Отже, популяції автологічних стовбурових мезенхімальних клітин залишалися гомогенними.

Перспективи подальших досліджень полягають у застосуванні експериментальних знань та навичок повного циклу виділення, культивування, фенотипування, диференціювання стовбурових клітин для ефективного застосування останніх у клінічних випробуваннях та підвищення якості проведеної клітинної трансплантації/ терапії.

Представлена робота є фрагментом науково-дослідницької тематики Харківської медичної академії післядипломної освіти МОЗ України: «Розробка технології отримання автоклітин різних типів біологічних тканин із стромальних клітин кісткового мозку $i$ застосування їх для лікування захворювань різного тенезу за допомогою автотрансплантації», номер № 0106U003995 (2013-2015pp.).

\section{Література}

1. Лисяный Н.И. Стволовые нервные клетки головного мозга и иммунная система / Н.И. Лисяный // Укр. неврол. ж. - 2011. - № 2. - С. 24-30.

2. Применение мезенхимальных стволовых клеток для восстановления структуры и функции поврежденных тканей и органов / И.Б. Бродский, С.А. Брянцева, О.Н. Жаппарова [ и др.] // Эфферент. и физ.-хим. мед. - 2011. - № 1. - С. 4-10.

3. Цымбалюк В.И. Нейрогенные стволовые клетки: между прошлым и будущим / В.И. Цымбалюк, В.В. Медведев // Лекарь. - 2008. - № 7. - С. 36-42.

4. American Heart Association [American Heart Association / Heart Disease and Stroke Statistics.] [Електронний pecypc]. - Update, Dallas TX, 2007. - P. 36-41. Режим доступу: http:// www. american heart.org/ statistics.

5. Barkho B.Z. Adult neural stem cells: response to stroke injury and potential for therapeutic applications / B.Z. Barkho, X. Zhao // Cell Res. Ther. - 2011. - Vol. 6. P. 327-338.

6. Bliss T.M. Transplantation Therapy for Stroke / T.M. Bliss, R.H. Andres, G.K. Steinberg // Neurobiol. Dis. - 2010. - Vol. 37. - P. 275-283.

7. Burns T.C. Stem cells and stroke: opportunities, challenges, and strategies / T.C. Burns, G.K. Steinberg // Expert Opin Biol Ther. - 2011. - Vol. 11. - P. 447-461.

8. Deficiencies in DNA damage repair limit the function of haematopoietic stem cells with age / D.J. Rossi, D. Bryder, I. Seita [et al. ] // Nature. - 2007. - Vol. 447. P. 725-729.

9. Ischemic cerebral tissue and MCP-1 enhance rat bone marrow stromal cell migration in interface culture / L. Wang, Y. Li, J. Chen // Experimental Hematology. 2002. - Vol. 30, Issue 7. - P. 831-836.

10. Liman T.G. New vessels after stroke: postischemic neovascularization and regeneration / T.G. Liman, M. Endres // Cerebrovasc. Dis. - 2012. - Vol. 33. - P. 492-499.

11. Lindvall O. Stem cell research in stroke: how far from the clinic? / O. Lindvall, Z. Kokaia // Stroke. - 2011. Vol. 42. - P. 2369-2375.

12. Neuronal differentiation of transplanted embryonic stem cell-derived precursors in stroke lesions of adult rats / C. Buhnemann, A. Scholz, C. Bernreuther // Brain. 2006. - Vol. 129. - P. 3238-3248.

13. Potentiation of neurogenesis and angiogenesis by G-CSF after focal cerebral ischemia in rats / Y. Sehara, T. Hayashi, K. Deguchi // Brain Res. - 2007. - Vol. 1151. P. 142-149. 
14. Safety of Cell Therapy with Mesenchymal Stromal Cells (Safe Cell): A Systematic Review and Meta-Analysis of Clinical Trials / M.M. Lalu, L. McIntyre, C. Pugliese [et al.] // Plos one. - 2012. - Vol. 7. - P. 475-479.

15. Sahota $\mathrm{P}$. Investigational therapies for ischemic stroke: neuroprotection and neurorecovery / P. Sahota,
S.I. Savitz // Neurotherapeutics. - 2011. - Vol. 8. P. 434-51,

16. Smith H.K The potential of stem cell therapy for stroke: is PISCES the sign? / H.K. Smith, F.N. Gavins // FASEB J. - 2012. - Vol. 26. - P. 2239-2252.

\section{ИММУНОФЛУОРЕСЦЕНТНЫЙ АНАЛИЗ: ОСНОВНЫЕ ЭТАПЫ ФЕНОТИПИРОВАНИЯ И ДИФФЕРЕНЦИАЛЬНИЙ ПОТЕНЦИАЛ АУТОЛОГИЧЕСКИХ СТВОЛОВЫХ МЕЗЕНХИМАЛЬНЫХ КЛЕТОК IN VITRO}

\section{И.И. Торяник, В.В. Колесник}

Резюме. В статье содержится развёрнутая информация о возможностях применения иммунофлуоресцентного анализа для изучения основних этапов фенотипирования и дифференцировки аутологических стволовых мезенхимальных клеток (АСМК) in vitro. Авторами работы представлены сведения, касающиеся происхождения клеток (самцы крыс линии Вистар 3- месячного возраста), способов их получения в лабораторных условиях (выделение из диафизов, эпифизов бедренной и большеберцовой костей животных с последующей промывкой культуральной средой, посевом на чашки Петри, эксплантацией, отмывкой от форменных элементов крови, культивированием в моношаре, пересевом). Указываются условия проведения фенотипирования (производили с применение проточной цитофлуориметрии, полученную ДНК полимеризовали со специфическими праймерами и завершали полимеразно-цепной реакцией). Продукты реакции анализировали методом электрофореза в агарозном геле. Дифференцировке в нейрональном направлении подвергали АСМК после второго пересева культуры. Для индукции дифференцировки использовали ростовой фактор нейротрофин-3. АСМК наращивали до плотного моношара. Фенотипирование полученых производных осуществлялось путем окраски клеток антителами до белковых маркеров нейронов специфического ядерного белка нейронов (NeuN) (Chemicon), нейрофибриллярного белка отростков (Tau) (Chemicon), миелин-олигодендроцит специфического белка (MOSP) (Chemicon), глиального фибриллярного кислого белка (GFAP) (Chemicon). В результате исследования было установлено: количество CD90+- клеток (которые собственно, и оказались популяцией АСМК) составляла соответственно 9597 \%. Фенотип клеток, определённый стандартно путем применения поверхностных маркеров, не изменялся в продолжение первых четырёх пассажей. Культивирование популяции АСМК в продолжение этих пассажей доказало, что они не теряли способности к дифференцировке в трёх основных ортодоксальных направлениях. Таким образом, популяции АСМК оставались гомогенными.

Ключевые слова: аутологические стволовые мезенхимальные клетки, иммунофлуоресцентный метод, фенотипирование, культивирование, дифференцировка, маркеры нейроцитов.

\section{IMMUNOFLUORESCENCE: MAIN STAGES OF PHENOTYPING AND DIFFERENTIAL POTENTIAL OF AUTOLOGOUS MESENCHYMAL STEM CELLS IN VITRO}

\section{I.I. Torianyk, V.V. Kolesnyk}

Abstract. The article contains detailed information about possible use of immunofluorescence for studying the main stages of phenotyping and differentiation of autologous mesenchymal stem cells (AMSCs) in vitro. The authors present facts, which concern origination of cells (3-month-old male Wistar rats), methods of their generation in laboratory conditions (isolation from femoral and tibial diaphyses and epiphyses of animals followed by washing with culture medium, inoculation on Petri dishes, explantation, cleaning from blood corpuscles, incubation in a monolayer, reinoculation). Conditions of phenotyping are described (with use of flow cytofluorometry, the received DNA was polymerised with specific primers and finished with a polymerase chain reaction). The reaction products were analysed by the method of electrophoresis in agarose gel. AMSCs were differentiated in the neuron direction after the second culture reinoculation. In order to induce the differentiation, neurotrophin-3 growth factor was used. AMSCs were grown up to a thick monolayer. The obtained derivates were phenotyped by staining cells with antibodies to protein markers of neurons, neuron-specific nuclear protein (NeuN) (Chemicon), neurofibrillary axonal protein (Tau) (Chemicon), myelin/oligodendrocyte-specific protein (MOSP) (Chemicon), glial fibrillary acidic protein (GFAP) (Chemicon). As a result of the study, it was revealed that the number of CD90+ cells (which actually proved to be the population of AMSCs) was $95-97 \%$. The phenotype of cells, determined on the standard basis by use of superficial markers, did not change during the first four passages. Incubation of the population of AMSCs during these passages proved that the above cells did not lose their ability to differentiate in three main orthodox directions. Thus, the population of AMSCs remained homogenous.

Key words: autologous mesenchymal stem cells, fluoroimmunoassay, phenotyping, incubation, differentiation, neurocyte markers.

Mechnikov Institute of Microbiology and Immunology of the NAMSU (Kharkiv) Romodanov Institute of Neurosurgery of the NAMSU (Kyiv)

Рецензент - проф. І.Й. Сидорчук

Buk. Med. Herald. - 2015. - Vol. 19, № 1 (73). - P. 173-177

Надійшла до редакції 15.12.2014 року

(C) I.І. Торяник, В.В. Колесник, 2015 